\title{
THE PORTRAYAL OF INDONESIAN IMAGE IN 2007 KOMPAS SELECTED SHORT STORIES: SOCIAL PROBLEMS, CRITICISMS AND HOPES
}

\author{
Akun \\ English Department, Faculty of Language and Culture, Bina Nusantara University, \\ Jln. Kemanggisan Ilir III No. 45, Kemanggisan/Palmerah, Jakarta Barat 11480, \\ akun@binus.edu
}

\begin{abstract}
Article aimed at exploring social problems reflected in 15 selected short stories printed in Kompas during 2007 both explicitly and implicitly. Specifically, this research is focused on the mapping of dominant social problems raised by the short stories, the social criticisms strongly voiced by the authors and the hopes of a better situation implicitly reflected in these interesting short stories. This study applies the Defamiliarization Effect promoted by Bertolt Brecht and Negative Dialectics or Negative Knowledge by Theodor Adorno, specifically in analyzing the literary works as a criticism tool. The result of the research shows that phenomena of social problems current lately in Indonesian context like identity, poverty, corruption, religious tensions, moral degradation, politics dirtiness, minority group problems, social security, natural disasters and the like are clearly seen and teased in these writings.
\end{abstract}

Keywords: social problems, social criticism, defamiliarization effect, negative dialectics, hopes

\begin{abstract}
ABSTRAK
Artikel mengupas permasalahan sosial yang tercermin di dalam 15 cerita pendek pilihan harian Kompas tahun 2007 baik secara gamblang maupun secara tersirat. Secara khusus, penelitian akan difokuskan pada pemetaan permasalahan sosial yang secara dominan diangkat oleh cerita pendek, kritik sosial yang disuarakan oleh para pengarang, serta sejauh mana harapan akan membaiknya keadaan secara implisit dipancarkan oleh cerita menarik ini. Penelitian ini akan menerapkan konsep Efek Defamiliarisasi Bertolt Brecht dan Dialektika Negatif Theodor Adorno terutama dalam mengkaji ceritaa tersebut dalam wujudnya sebagai sebagai alat kritik. Fenomena permasalahan sosial yang marak belakangan ini seperti identitas, kemiskinan, korupsi, keagamaan, kemerosotan moral, kebobrokan politik, kelompok minoritas, keamanan sosial, bencana alam dan semacamnya terbukti secara kental diangkat dan diusik melalui tulisanini.
\end{abstract}

Kata kunci: permasalahan sosial, kritik sosial, efek defamiliarisasi, dialektika negatif, harapan 


\section{INTRODUCTION}

Short stories, when most of all presented through nationally distributed and acclaimed newspaper such as Kompas Daily, for sure bring rich national social problems current in this country to the surface. In some way, when an author jots down her or his ideas into (short) stories, actually at the same time she or he is also jotting down whether consciously or unconsciously her or his responses and thoughts on what are flaring up in her or his surroundings, and of what interests her or him much. Donald Hall has stated about this when he wrote, "Whatever people do, they express the times they live in. When authors write, they reflect their own era by deploring it, by celebrating it, or even by writing to escape it" (Hall, 2002: 1275). This mostly means that those authors crystallize their life experiences in responding to life phenomena and do it in different ways: some may criticize and mock, some others celebrate with full expectation, and even some probably write to escape the reality because they feel restless, embarrassed and infuriated towards the social life condition that keeps worsening and getting harder. Whatever the forms and reasons, a work is consequently and certainly born either directly or indirectly because of it.

Kompas Daily is a consistent and efficient medium to accommodate these worries, complaints and hopes by selecting (with its own certain considerations and restriction, of course!) and publish all the stories regularly every week accompanied by the illustrating pictures that cannot be equalized to the stories themselves because illustrated pictures are seen as independent creative works that cannot easily represent the short stories. Around 50 short stories are published every year and about 15 stories will be chosen as the best selected stories with one selected best short story then decided as the title of the collection to finally be republished.

According to the managing director of Kompas (Pambudy, 2008:ix), the last three years (2006, 2007, 2008) the mechanism of selecting the stories has been changed and developed by not involving the inside committee from Kompas anymore, different from what has traditionally done for so many years. The new mechanism involves people from outside Kompas management considered to be competent of giving judgment on this selection process. In 2006, Nirwan Dewanto and Bambang Sugiharto got the honor to do the selection process and they resulted the anthology called Ripin named after the chosen best short story, while in 2007 Ayu Utami and Sapardi Djoko Damono di the responsibility with Cinta di atas Perahu Cadik as the result, and the last in 2008, Rocky Gerung and Linda Christianity did the job and they came up with Smokol. For this study, I am going to discuss only one of them i.e. the 2007 anthology.

Referring back to a fictitious literary work as a mirror reflecting what is flaring up in the society responded by certain authors (they are possibly flaring up themselves!), I am going to elaborate some dominant social problems found in the anthology, what social criticisms are delivered, and how are hopes still seen to be symbolically brought by the stories although the situation is quite gloomy.

Some of the short stories uniquely make use of the characters and explore unusual themes. For that reason, an appropriate approach is needed to discuss the stories so that the conveyed message can be well understood. In short, the theoretical perspective promoted by Bertolt Brecht with his concept of Defamiliarization Effect and Theodor Adorno’s Negative Knowledge are going to be applied.

Bertolt Brecht is known for his alienation concept (developed from Russian Formalist's defamiliarization concept) which is much practiced and applied in drama performance. Brecht labeled his developed realism theory as "anti-Aristotelian". If Aristotle's concept stresses much on the universality and unity of tragedy elements that end in their success on providing audience (also readers) with emotion catharsis by having empathy on the story characters and drifted away in the story plot, Brecht on the other hand showed his opposition against this concept. He said that the plot of 
the story which is structured in such a way that can make the audience drifted away must be avoided. The reason is simple; the social injustice must be presented as something unnatural and truly shocking, not as an integral and natural part of the story which is oftentimes unable to be recognized consciously anymore.

"It is all too easy to regard 'the price of bread, the lack of work, the declaration of war as if they were phenomena of nature: earthquakes or floods', rather than as the results of exploitative human agency" (Selden, Widdowson \& Brooker, 1997:97).

Therefore, to avoid the fact of drifting the audience or readers in the form of accepting social reality passively, it is suggested to shake the illusion of the reality in a deplorable and shocking way through the usage of alienation effect presented through the characters that are easily recognized but seem to be so strange at the same time. According to Brecht, only through this way critical judgments can be produced by people who enjoy the work. Further, Brecht emphasized that the elements inside the character have to be understood from outside, and depicted not as simple and familiar but the other way around, "The situation, emotions and dilemmas of characters must be understood from the outside and presented as strange and problematic" (pp98).

By applying the alienation technique, Brecht actually was not a faithful follower of realism (although this is still debatable), because if this alienation effect is applied to realism formula, he will fail:

"Brecht would have been the first to admit that, if his own 'alienation effect' were to become a formula for realism, it would cease to be effective. If we copy other realists' methods, we cease to be realists ourselves: 'Methods wear out, stimuli fail. New problems loom up and demand new techniques. Reality alters; to represent it the means of representation must alter too'." (pp99).

The above quoted lines are in line with Ayu Utami's prolog in the anthology when she argued upon her choice of fifteen selected stories included in the anthology, in which she questioned "Why Realism is not enough anymore? " The fact that realism used in the old time, used to be enough, is now not enough anymore. What actually makes it insufficient? (Pambudy, 2008:xiii-xiv).

Further, Sapardi Djoko Damono mentioned non-realist stories that sound strange as "fable" (pp139). For me, to understand and analyze these selected literary works does need a different approach, and here it goes when Brecht's method is felt to serve best the purpose.

Besides, a similar approach which is developed by Theodor Adorno is considered to necessary to complete the understanding of these selected stories. For Adorno, a work of art, including a work of literature, will contain more strength in criticizing reality if the piece of work is separated from the very reality:

"For Adorno, art, including literature, is detached from reality and this is the very source of its strength. Popular art forms only confirm and conform to the norm of a society but true art takes up a critical stance, distanced from the world which engendered it: 'Art is the negative knowledge of the actual world.' He saw the alienation evident in the writing of Proust and Beckett as proving such 'negative knowledge' of the modern world" (Carter, 2006:60);

Next, Selden and friends added that in Adorno's view literary works have no direct connection with reality, not as Lukacs' view about realism:

"Adorno criticized Lukacs' view of realism, arguing that literature does not have a direct contact with reality. In Adorno's view, art is set apart from reality; its detachment gives it 
its special significance and power. Modernist writings are particularly distanced from the reality to which they allude, and this distance gives their work the power of criticizing reality" (Selden, Widdowson \& Brooker, 1997: 100).

Therefore, the process of separating or distancing between literary work and reality is a necessary process which supposedly constitutes an alienation process where literature lovers are presented with strange unnatural problems. Only through this way the readers or audience will never felt drifted and finally understand the criticism targets aimed by the literary work.

For Adorno, a work of art cannot merely reflect the social system within a society, but it can at the same time play a role in that society as a "teaser" of which existence is sometimes irritating, and then negating the reality, which finally results in an indirect understanding of what is famously known as "Art is the negative knowledge of the actual world" (100) as has been slightly discussed above.

In relation to Kompas selected short stories to be analyzed in this study, I have decided to discuss 4 (four) short stories which are in my opinion very interesting and full of the process of distancing from realities in this country which are so easy to be recognized but at the same time so strange (through the use of alienation/ defamiliarization effect I suppose); they are: Cinta di Atas Perahu Cadik (Love on a Small Boat by Seno Gumira Ajidarma), Lampu Ibu (Mother's Lamp by Adek Alwi), Kisah Pilot Bejo (Pilot Bejo's Story by Budi Darma), dan Tukang Jahit (The Sewer by Agus Noor). The analysis will be started by exploring and surfacing the social problems raised by the short stories, and then discuss how far those stories or “fables"--to borrow Damono's term-distance themselves from the readers and then targeting the social phenomena being criticized, and lastly, there will be a discussion on hopes for a better future, at least symbolically, that are still in anyway shining through the stories.

\section{RESEARCH METHOD}

This is a library research of the four selected short stories mentioned above through a close reading of the texts (the stories) by applying the concept of Defamiliarization Effect promoted by Bertolt Brecht and Negative Dialectics or Negative Knowledge by Theodor Adorno.

\section{RESULTS AND DISCUSSION}

There are various social problems raised by Kompas selected short stories in this anthology. To mention a few, we have social problems on love affairs and moral degradation which are obviously not only screened much on television or film theatres (Cinta di Atas Perahu Cadik), problems around poverty and injustice (Tukang Jahit, Cinta di Atas Perahu Cadik), corruption, pretense and role playing (Lampu Ibu), the wrack or collapse of public service (Kisah Pilot Bejo), drugs problems (Lampu Ibu), modern culture invasion (Lampu Ibu, Kisah Tukang Jahit) and other social problems.

I observed beyond the surface and in depth, the four short stories actually present the problems differently and shockingly, that are sometimes beyond the readers' expectation. The readers are left with no choices but to accept the reality that even though the problems seem to be common and natural, they are totally represented through weird characters and properties (Tukang Jahit, Pilot Bejo, Lampu, Sukab-Hayati-Waleh-Dullah). In this way, the readers will feel alienated and not drifted in the form of sympathy towards the characters or events. 
When reading Cinta di Atas Perahu Cadik, we will find something strange and shocking, for example how come a husband (Dullah) gives permission to his own wife (Hayati) to sail-have love affair with someone from the same village (Sukab) and prefers watching TV to commenting on or concerning about his wife's leaving with the other guy to whom according to the old lady (who also has had enough experience in love affair) he should have killed him, "sudah mencabut badik dan mengeluarkan usus Sukab jahanam itu!” (p. 3). Or the attitude from Sukab’s wife (Waleh) who should have been tortured, poor, given birth to a mute child, and been ill for long because of her husband's betrayal, but then gives her agreement and prays for her cheating husband's happiness with the new other woman (Hayati),

"Aku memang hanya orang kampung, Ibu, tetapi aku tidak mau menjadi kampungan yang mengumbar amarah menggebu-gebu. Kudoakan suamiku pulang dengan selamat-dan jika dia bahagia bersama Hayati, melalui perceraian, agama kita telah memberi jalan agar mereka bisa dikukuhkan"

(p. 6).

What a shocking response; a mentally tortured wife with an angel's heart who is so hard to find nowadays!

The more shocking part is the fact that this love affair is open and nobody feels awkward at all even from the doers of the affair (Kukeb-Hayati) just like a normal or common couple of lovers (remember this is NOT common!) the world seems to belong to them only; parents, children, neighbors, parents in law do not need to be given any care or attention, what matters is only their romance, "-tetapi mata keduanya menyala-nyala karena semangat hidup yang kuat serta api cinta yang membara" (p. 8), what counts is their instant happiness and they like it even though it is bad and morally wrong if related to faithfulness to their previous wife or husband. Moreover, they fully understand of what they are doing as mature adult people as emphasized at the end of the story, "Namun keduanya juga mengerti, betapa bukan urusan siapa pun bahwa mereka telah bercinta di atas perahu cadik ini” (p. 9); who cares!

This is how we are shocked by the uncommon and strange attitude showed by the characters in the story. Although the love affair theme is so common found in daily experiences around us, we still feel alienated by this reality inside the story. By this way, we cannot indeed be drifted along the storyline (no experience of Aristotle's catharsis), what exists on the other hand is feelings of irritation and finally we realize that all problems are not merely black and white, that we cannot at once blame anybody that easy, and here is the criticism intended by the author and his work seems to serve the purpose.

In the next short story, Lampu Ibu, we are faced with the role playing and lamp metaphor, which is so close to our daily life, but then when it is put side by side to the word ibu (mother), it becomes strange: lampu ibu? What is actually lampu ibu? This story of corrupt political leaders' habits and attitudes, which practice corruption in togetherness, depicts how a politician, some sort of members of the parliament, can pretend to be sick in order to be free of legal charge or at least postpone the police arrest on their illegal practice. There is at the start a doubt about the story of corruption involvement here whether the accused Bang Palinggam is really involved or really clean. His confession stresses that, "Namun, hingga detik ini, Bunda, aku tetap bersih. Terkutuk aku bila mendustai Bunda,"(p.17). The confession from the politician's mouth strongly states that he is clean, he even takes a vow against his mother or condemns himself if he is not truthful on this matter, but at the beginning it is described that he sounds to need an apology, "Suara Bang Palinggam terdengar pelan, sayu, seperti minta dimaafkan”

(p. 17). Why does he need apology for if he is clean? The next part seems to contradict Bang Palinggam's early confession and defense that strongly suggests his involvement 
"Kalau begitu, mengapa kau mengelak diperiksa, Nak? Kenapa berpura sakit? Mengapa tidak kau beberkan saja semuanya?'

'Tidak sesederhana itu, Bunda.'

'Di mana rumitnya?'

Tidak terdengar suara. Aku muncul. Abangku melirik. Menarik napas, melihat Bunda lagi. Mukanya kuyu. Loyo.

'Aku punya atasan, Bunda,' ujarnya bak mengadu. Suaranya makin lunak, menyerupai bisik. 'Aku punya kawan. Aku juga kader partai....' (p. 17).

hampir

It is clear then that Bang palinggam is directly or indirectly involved in committing corruption crime so that he is described to be so trembling and weak and finally after being lectured by the mother he slowly cries: "terpana menatap Bunda. Matanya perlahan berkaca-kaca. Dia menunduk" (p. 17).

Indeed, the content of the story is related much with the pretense and hypocrisy. For example, we are forced to be involved in the situation awkwardness of the son who picks up her mother to the airport because he tries hard to cover what really happens to the family (although the mother has actually known what happens), or the pretending situation about the arrest of Herman as a character by the police because of his involvement in drug abuse and then covered up as going away for a mountain climbing. The content is full of pretense. However, going back to the lamp that seems strange, this story is shocking us with the presence of a mother character that never stops lighting the "lamp light" of honesty and truth. Do we feel sympathy toward the mother who even though has been 80 years old is still busy controlling her children and grandchildren? From the awkwardness of situation described earlier, it is strongly felt that the mother's presence is considered as "obstacle" that requires pretense. Once again, the title with the word "lamp" for me is a tool to make us distance the corruption reality strongly seen around us, especially in the politics realm as conducted by Bang Palinggam, and the mother image that is so determined in lighting or voicing the honesty and truth with no certainty and indication for its success.

The next story, Kisah Pilot Bejo, shows that alienation effect applied inside the story is more obvious. Almost all parts of the story are presented in the form of a storyline to clearly ridicule through the use of some comical characters, such funny but representative names as Bejo, Slamet, Untung, Sugeng, Waluyo, Wilujeng, Paman Bablas, dokter Gemblung, AA (Amburadul Airlines), SA (Sontholoyo Airlines). We are removed or distanced from the present mushrooming airlines industries, including the high frequency of flight accidents - also including the disappearance of planes and hundreds of passengers inside through the presence of this super neglectful Bejo pilot's extraordinary story. We know that the reality on this Bejo pilot who since his high school time (even from his being inside his mother's womb, perhaps) has relied on his being lucky is only a tool for the author to shock the readers - a tool to distance the literary work from reality - in order to realize how disastrous and bad our airlines reality has been. Pay attention to the expression used by the author as follows:

"Dibanding dengan ayahnya, kedudukan pilot Bejo jauh lebih baik, meskipun pilot Bejo tidak lain hanyalah pilot sebuah maskapai penerbangan AA (Amburadul Airlines) yaitu perusahaan yang dalam banyak hal bekerja asal- asalan. Selama tiga tahun AA berdiri, tiga pesawat telah jatuh dan membunuh semua penumpangnya, dua pesawat telah meledak bannya pada waktu mendarat dan menimbulkan korban-korban luka, dan paling sedikit sudah lima kali pesawat terpaksa berputar-putar di atas untuk menghabiskan bensin sebelum berani mendarat, tidak lain karena rodanya menolak untuk keluar. Kalau masalah keterlambatan terbang, dan pembuatan jadwal terbang asal-asalan, ya, hampir setiap harilah” (p.20).

Every day is passed by the practice of reckless management of the airline, what is important is gaining profit as much as possible (in line with the capitalist boss' wishes), meanwhile the passengers or 
customers' need is never prioritized or even considered, even until the end of the story, there is no change, the lucky Bejo still clings to his working principle.

"Semua penumpang menjerit-jerit, demikian pula semua awak pesawat termasuk kopilot, kecuali dia yang tidak menjerit, tetapi berteriak-teriak keras:'Bejo namaku! Bejo hidupku! Bejo penumpangku!' Pesawat berderak-derak keras, terasa benar akan pecah berantakan” (p. 26).

All is reckless, and this functions in Adorno's view as an irritant so that the readers are positioned that is distanced from reality in order for them to be able to have critical perspectives toward the reality being raised by the literary work and finally criticize the very reality existing around them.

In the last short story Tukang Jahit, the use or exploitation of the character and plot by the author in the story which is experimentalist also happens. Although the story seems to a fairy tale as commented by Ayu Utami (Pambudy, 2008:xxii), for me this a way used by the author to once again through the use of the "sewer"metaphor to criticize Indonesian people's life reality that is getting harder, finally culminating to a reality signaled by the fact of "queuing for kerosene" (p. 105). Getting back to the use of metaphor, I agree with Sapardi Djoko Damono who has stated that language device can distance us from reality because we can mention A to mean B or mention B to mean C or A, and so on: "piranti bahasa ini jelas menjauhkan kita dari realitas karena 'bilang begini maksudnya begitu' (p. 145)". Thus in this way, the effect wanted by the author can work properly: to distance the readers from the reality raised in the story so that they can have a strategic position to see clearly what is being criticized by the author with his work and finally be critical on the existing reality, because if quoting back Bretch - facts about social injustice must be presented as if the reality is so unnatural and shocking, not as facts so integrated with the readers or audience that need to be cried for like the ones in television series so that the readers are made to forget their reality and do not have the ability to criticize the reality.

The storyline of this Tukang Jahit comprises of impossible things in denotative meanings like "menjahit hati orang yang lagi sedih" (p. 102), "menjahit luka hati Ibu” (p. 103), ”...bisa melihatnya, tetapi tak bisa menyentuhnya. Benang yang tak akan habis bila dipakai untuk menjahit seluruh pakaian yang ada di dunia ini" (p. 103), "memintal benang kesabaran" (p. 104), "menjahitkan kekecewaan" (p. 105), and some other instances. All cannot be understood in a direct way, but interestingly they are put side by side with the real and so easily understood everyday realities such as "Lebaran" (pp. 99, 100, 102, 103, 104, 105) "toko fashion, factory outlet, butik dan pusat perbelanjaan di kota" (p. 102), "ngantre minyak tanah" (p. 105), "pulang kampung” (p. 106), "nganggur" (p. 106), and so on. This can absolutely create defamiliarization effect, so close but at the same time so strange, that cannot drift the readers with the story but to trigger critical thoughts toward the harsh realities being discussed.

The social problems put forward by the four short stories are full of real problems in this country. If I may summarize the problems are moral degradation such as love affair, corruption, ignorance due to capitalism domination and poverty. The next question is whether there is a hope of being free from this social problems implied in these four short stories. Out of the four, Kisah Pilot Bejo is the most cynical and hopeless. With its cynical, mocking and sarcastic tone, the author ends the story with the most unorganized situation in the airlines industry. There is no optimistic character believing that this rotten condition is possible to be fixed (perhaps the author feels the same way too!). The only optimistic character is Bejo who is deeply drowned in the super unorganized and corrupt airline system.

However, behind the other three stories, if studied in depth, we can still find implied hopes for a better situation beyond the darkness of the depicted realities. Coincidentally, they still present three female characters who have idealism (does this mean women are more sensitive toward these social 
phenomena?) in facing the difficult situation. In Cinta di Atas Perahu Cadik, an old grandmother is presented as someone who feels sick (read: care) of the Sukab-Hayati's love affair. She is the one who moves the story forward because she is so irritated and goes here and there without being able to be ignorant of what happens. Besides, she wants to convey a moral message to women especially that her bad past experience of being cheated by her husband may not happen to her next fellow generation. At least, if there is someone who cares just like this old lady, then the hope to change is still there.

Next, in Lampu Ibu, it is clear that we can meet similar character, a mother of 80 years old, a grandmother too, who never feels tired of lighting the lamp of honesty and truth, as stated at the end of the story, "Kalian sekarang memang bukan lagi anakku yang dulu.' Bunda mengedarkan senyum, juga kepadaku.'Apalagi kau, Palinggam, kini sudah bercucu pula. Namun takdir seorang ibu, Nak, selalu terdorong menyalakan lampu hingga akhir hayatnya” (p. 18). It is obviously seen that the mother is not hopeless, still keeps her smile although she knows her son has been deeply involved in the act of putting off his mother's lamp, but still she keeps struggling this the end to set fire to the lamp because she is a caring character.

Finally, in Tukang Jahit, once again another mother character (who finally becomes a grandmother too at the end of the story she is presented as a child asking her father) is presented as a figure with wisdom and hope not to give up against life difficulties. She is a mother who has an understanding of high life philosophy mainly in facing poverty. This is proven because at the end this mother is successful in transferring the understanding of life philosophy to her child (then transferred to the child's own child) so that the child can understand why there are so many people who are unhappy in this country due to the high price of that happiness, as mentioned in this quotation:”Barangkali, sekarang ini kebahagiaan memang seperti minyak tanah. Tidak semua orang dengan gampang mendapatkannya. Bahkan untuk sekadar bisa menikmati kebahagiaan pada hari Lebaran pun kini orang mesti antre berdesak-desakan" (p. 106). So, even though the situation is so difficult, the mother and her child-grandchild are depicted in this story as not hopeless, but understand the situation. The symbolic hope is still owned by them because in anyway there are still sewers who can sew all sad, disappointed and broken hearts, and other thousands of grieves and sorrows.

\section{CONCLUSION}

Every story can be read as a medium that reflects whatever happens in the real world. But not all stories present the life realities as they are with convincing storylines that can drift the readers away in the conflicts so that they forget or insensitive toward the social criticism aimed by the story. This is in line with Bertolt Brecht and Theodor Adorno who both emphasize the importance of alienation effect or defamiliarization effect created by the story that has the capability of creating a distance between the literary work and the real world, that this literary work functions to irritate the readers so that they can criticize the reality. Out of the four short stories chosen in this study, it is proven that the authors present the storylines and characters that are not common, mostly shocking, to give space for the readers to criticize the raised social phenomena. In this way, the readers can have a more strategic and objective standing position in understanding the social criticism aimed by the authors, and thus becoming more critical too toward the reality. The social problems such as love affairs, corruption, totally unorganized public services and also poverty that have lately colored the face of this country have been presented by the authors through their special way, and behind all the social problems, the hope for a better future is still implicitly seen through the presence of old female characters who seem to be irritated and hopeless but actually remain caring. 


\section{REFERENCES}

Carter, D. (2006). Literary Theory: The Pocket Essential. Herts: Pocket Essentials

Hall, D.( 2002). To Read Literature: Fiction, Poetry, Drama. Boston: Heinle \& Heinle Thomson Learning.

Pambudy, N.M. (ed). (2008). Cinta di Atas Perahu Cadik: Cerpen Kompas Pilihan 2007. Jakarta: Penerbit Buku Kompas.

Selden, R., Widdowson, P., \& Brooker, P. (1997). A Reader's Guide to Contemporary Literary Theory. London: Prentice Hall. 